\begin{tabular}{ccc}
\hline Jurnal Pendidikan Biologi 8 (2) (2019) $46-54$ \\
Jurnal Pendidikan Biologi
\end{tabular}

\title{
Pengaruh Model 3C3R Terhadap Kemampuan Literasi Sains Siswa pada Konsep Interaksi Mahluk Hidup Dengan Lingkungan
}

\author{
Gendis Siti Rahmawati, Sistiana Windyariani, Suhendar \\ Pendidikan Biologi, FKIP, Universitas Muhammadiyah Sukabumi, Jl. R. Syamsudin, S.H, No. 50, Kota Sukabumi, \\ Jawa Barat, Indonesia
}

\section{INFO ARTIKEL}

Histori Artikel

Received 17 Juni 2019

Revised 19 Juni 2019

Accepted 26 September 2019

Published 9 Desember 2019

Keywords:

3C3R Learning Model, PBL Approach,

Science Literacy

\begin{abstract}
This study aims to determine how the influence of the 3C3R learning model (Content, Context, Connection, Reading, Reasoning, Reflecting) on students' literacy skills after learning in the concept of interaction between living things and the environment. The sample of this study was grade VII students in SMP Negeri 13 Kota Sukabumi which were taken using a pusposive sampling technique with 24 students in the experimental class and 25 students in the control class. The instrument of this research is a matter of testing scientific literacy skills. This type of research is Quasi Experimental with a non equivalent control group design research design. The data analysis technique uses the $t$ test with a significance level of $\alpha 0.05$. From the results of the $t$ test, the conclusion is that $\mathrm{H} 0$ is rejected and $\mathrm{H} 1$ is accepted, meaning that there are significant differences in students' scientific literacy skills between the experimental class and the control group. So it can be concluded that the 3C3R learning model influences students' scientific literacy abilities. The benefits of this study can affect students' scientific literacy skills which will be very useful for students.
\end{abstract}

Copyright (C) 2019 Universitas Negeri Medan. Artikel Open Access dibawah lisensi CC-BY-4.0 (https://creativecommons.org/licenses/by/4.0)

\section{How to Cite}

Rahmawati, G. S., Windyariani, S., \& Suhendar. (2019) Pengaruh Model 3C3R Terhadap Kemampuan Literasi Sains Siswa pada Konsep Interaksi Mahluk Hidup Dengan Lingkungan. Jurnal Pendidikan Biologi, $8(2), 46-54$.

\section{PENDAHULUAN}

Pendidikan internasional saat ini berfokus pada pentingnya literasi sebagaimana tercantum dalam tujuan EFA (Education For All) yang ditetapkan oleh UNESCO. UNESCO percaya bahwa orang berliterasi akan membantu memecahkan berbagai masalah dan akan mendukung pembangunan berkelanjutan. Salah satu topik literasi yang penting bagi seluruh warga negara adalah literasi sains (Udompong \& Wongwanich, 2014).

Literasi sains merupakan kemampuan yang penting dan dibutuhkan pada era digital saat ini. Pentingnya literasi sains karena permasalahan saat ini berkaitan dengan pengetahuan dan teknologi. Selain itu kemampuan yang dapat memberdayakan masyarakat untuk membuat keputusan pribadi dan berpartisipasi dalam perumusan kebijakan 
publik yang berdampak pada kehidupan adalah kemampuan literasi sains (Kusuma, 2016).

Literasi sains menurut PISA (Programme for International Student Assessmen), (2010) dalam Odja \& Payu, (2014) adalah kemampuan menggunakan pengetahuan sains untuk mengidentifikasi permasalahan dan menarik kesimpulan berdasarkan bukti-bukti dalam rangka memahami serta membuat keputusan tentang alam dan perubahan yang dilakukan terhadap alam melalui aktivitas manusia. Hampir pada seluruh negara maju maupun negara berkembang saat ini memiliki tujuan yang sama, yaitu dapat meningkatkan kemampuan literasi sains siswa yang diharapkan dapat diintegrasikan dengan tujuan pembelajaran di sekolah. Sehingga tujuan pembelajaran ini juga menjadi fokus sekolah yang ada di Indonesia (Shofiyah, 2016).

Berdasarkan hal tersebut, maka dalam kegiatan pembelajaran di sekolah perlu dilatihkannya soal-soal literasi sains kepada siswa dan perlu diterapkannya suatu model yang menekankan terhadap aspek kontekstual dan pemecahan masalah yang dapat berpengaruh terhadap kemampuan literasi sains siswa. Salah satu model yang diprediksi dapat berpengaruh terhadap kemampuan literasi sains siswa adalah model pembelajaran 3C3R (Content, Context, Connection, Reseacrhing, Reasoning, Reflecting). Model pembelajaran $3 C 3 R$ merupakan inovasi model pembelajaran, berorientasi pada pendekatan PBL (Problem Based Learning) yang diciptakan oleh Whoei Hung (Hung, 2009).

Dalam model pembelajaran $3 C 3 R$ memiliki dua komponen yaitu komponen inti dan komponen pengolahan. Komponen inti terdiri dari content, context, dan connection. Komponen 3C ini berhubungan dengan isi atau konsep pembelajaran yang akan diolah oleh komponen pengolahan $3 \mathrm{R}$ yang terdiri dari researching, reasoning, dan reflecting yang mendukung proses kognitif pemecahan masalah dan keterampilan berpikir yang dimiliki siswa. Adapun tahapan model pembelajaran $3 C 3 R$ adalah; Researching content, Researching context, Researching connection, Reasoning content, Reasoning context, Reasoning connection, Reflecting content, Reflecting context, Reflecting connection (Hung, 2012).

Model pembelajaran $3 C 3 R$ merupakan model pembelajaran yang termasuk ke dalam pendekatan pembelajaran berbasis masalah. Pembelajaran berbasis masalah telah terbukti menjadi salah satu alat belajar paling efektif dalam pendidikan untuk mendorong pemikiran kritis, memahami konsep-konsep yang sulit, mengembangkan daya ingat pengetahuan dan dapat mengaitkan dengan situasi kehidupan nyata (Munasinghe, et al., 2010).

Terdapat teori pembelajaran yang mendukung pembelajaran berbasis masalah. teori belajar yang mendukung model pembelajaran berbasis masalah yaitu teori konstruktivisme. Teori konstruktivisme merupakan sebuah teori yang ingin merubah paradigma suatu logika yang memandang bahwa pengetahuan sebagai sesuatu yang mutlak, menjadi bahwa pengetahuan disusun secara individu. Teori ini menekankan siswa pada keterlibatan suatu masalah dengan maksud agar siswa dapat menyusun pengetahuan mereka sendiri dari hasil pemikiran terhadap penyelesaian masalah yang sudah ditemukan. (Husna \& Himmi, 2019).

Berdasarkan latar belakang yang telah dipaparkan di atas, maka tujuan penelitian ini adalah untuk mengetahui bagaimana pengaruh model pembelajaran $3 C 3 R$ terhadap kemampuan literasi sains siswa pada konsep interaksi mahluk hidup dengan lingkungan. Penelitian ini diharapkan dapat menjadi 
informasi penting dalam upaya melatihkan kemampuan literasi sains siswa.

\section{METODE}

\section{Jenis Penelitian}

Jenis penelitian yang digunakan adalah Quasi Eksperimental dengan desain penelitian non equivalent control group design. Variabel dalam penelitian ini terdiri dari dua variabel yakni, model pembelajaran $3 C 3 R$ sebagai variabel bebas, dan kemampuan literasi sains siswa pada konsep interaksi mahluk hidup dengan lingkungan sebagai variabel terikat.

\section{Subjek Penelitian}

Subjek yang digunakan pada penelitian ini adalah siswa kelas VII SMP Negeri 13 Kota Sukabumi, Jawa Barat. Pengambilan sampel dilakukan dengan teknik pusposive sampling artinya pengambilan sampel dilakukan dengan pertimbangan tertentu. Subjek yang digunakan terdiri dari dua kelas yakni kelas kontrol dengan jumlah 25 siswa dan kelas eksperimen dengan jumlah 24 siswa dengan pengambilan sampel tidak dilakukan secara acak.

\section{Analisis Data}

Teknik analisis data yang dilakukan dari hasil uji coba soal tes kemampuan literasi sains berbentuk pilihan berganda sebanyak 30 soal yang mengacu pada indikator literasi sains menurut OECD, (2016) yakni menggunakan uji validitas, uji realibilitas, daya pembeda, dan tingkat kesukaran menggunakan aplikasi Anates v4. Dari hasil analisis data diperoleh instrumen soal tes kemampuan literasi sains yang telah memenuhi kriteria sebanyak 16 butir soal. Soal tersebut selanjutnya diberikan kepada kelas eksperimen dan kelas kontrol untuk melakukan pretest sebelum melakukan kegiatan pembelajaran dan posttest setelah melakukan kegiatan pembelajaran. Pada kelas eksperimen kegiatan pembelajaran dilakukan dengan model pembelajaran $3 C 3 R$ sedangkan pada kelas kontrol kegiatan pembelajaran dilakukan dengan pembelajaran konvensional dengan model pembelajaran Group Investigation.

Teknik analisis data yang digunakan dari hasil pretest dan posttest yang diperoleh dengan menghitung nilai $N$-gain, kemudian dilakukan Uji Normalitas dan Uji Homogenitas untuk mengetahui bahwa sampel berdistribusi normal dan homogen dengan signifikan $\alpha$ 0,05 . Selanjutnya dilakukan Uji Hipotesis menggunakan uji $\mathrm{t}$ dengan signifikan $\alpha 0,05$ karena jumlah sampel $<30$ dan sampel yang diperoleh berdistribusi normal dan homogen.

\section{HASIL DAN PEMBAHASAN}

Literasi sains merupakan kemampuan yang diperlukan di era digital saat ini. Kemampuan literasi sains juga diperlukan untuk membantu memecahkan masalah yang berkaitan dengan pendidikan dan teknologi saat ini. Berdasarkan hal tersebut peneliti ingin mengetahui kemampuan awal literasi sains siswa SMP Negeri 13 kota Sukabumi dengan melakukan observasi awal di sekolah tersebut. Hasil yang didapatkan bahwa kemampuan literasi sains siswa di sekolah tersebut masih rendah. Hal tersebut disebabkan karena siswa belum menguasai aspek indikator literasi sains, salah satunya menafsirkan data dan bukti secara ilmiah. Hal tersebut ditunjukkan dengan belum mampunya siswa mengkomunikasikan dengan baik apa yang sudah mereka pelajari dalam kegiatan pembelajaran. Siswa di sekolah tersebut juga lebih terbiasa mengerjakan soal-soal yang bukan termasuk soal literasi sains. Berdasarkan hal tersebut peneliti mencoba melakukan penelitian dengan menggunakan model pembelajaran $3 C 3 R$ pada kelas eksperimen untuk melihat pengaruh model pembelajaran tersebut 
terhadap kemampuan literasi sains siswa, yang kemudian dilihat perbandingan kemampuan literasi sains nya antara kelas kontrol dan kelas eksperimen dan dilihat pula nilai $\mathrm{N}$-gain dari setiap indikator literasi sains.

\section{Perbedaan kemampuan literasi sains}

Berdasarkan hasil penelitian terdapat perbedaan kemampuan literasi sains siswa antara kelas eksperimen dan kelas kontrol. Hal tersebut terlihat dari perbedaan rata-rata pretest dan posttest yang disajikan pada Tabel 1 .

Tabel 1. Rekapitulasi Nilai Rata-rata pretest dan posttest pada Kelas Eksperimen dan Kelas Kontrol

\begin{tabular}{ccc}
\hline \multirow{2}{*}{ Kelas } & \multicolumn{2}{c}{ Nilai Rerata Kemampuan Literasi Sains } \\
\cline { 2 - 3 } & Pretest & Posttest \\
\hline Eksperimen & 43,98 & 80,19 \\
Kontrol & 42,97 & 67,98 \\
\hline
\end{tabular}

Berdasarkan Tabel 1 di atas perolehan nilai rata-rata pretest pada kelas eksperimen sebesar 43,98 sedangkan pada kelas kontrol sebesar 42,97. Setelah dilakukan kegiatan pembelajaran dengan model pembelajaran yang berbeda, diperoleh peningkatan nilai posttest pada kelas eksperimen yakni meningkat menjadi 80,19 sedangkan pada kelas kontol meningkat menjadi 67,98 . Selain itu nilai nilai $N$-gain yang diperoleh pada kelas eksperimen sebesar 0,65 sedangkan pada kelas kontrol sebesar 0,42. Berdasarkan data di atas terlihat bahwa pada kelas eksperimen dengan menggunakan model pembeajaran $3 C 3 R$ mendapatkan perolehan nilai rata-rata $N$-gain, pretest dan posttest yang lebih besar dibandingkan dengan kelas kontrol dengan menggunakan pembelajaran konvensional dengan model pembelajaran Group Investigation.

Hal tersebut membuktikan bahwa model pembelajaran $3 C 3 R$ dapat mempengaruhi kemampuan literasi sains siswa, karena dalam proses pembelajarannya dengan menggunakan model pembelajaran tersebut siswa diarahkan dengan proses mencari tahu, mengemukakan pengetahuan yang mereka miliki serta membantu untuk membentuk hasil belajar yang diaplikasikan dalam kehidupan nyata, dan membuat siswa selalu aktif dalam pembelajaran yang dapat melatihkan kemampuan literasi sains siswa. Hal ini sesuai dengan pendapat Techakosit \& Wannapiroon, (2015) mengungkapkan bahwa proses researching, reasoning, dan reflecting pada lingkungan belajar dapat meningkatkan kemampuan literasi sains.

Setelah dilakukan perhitungan nilai pretest dan posttest pada kelas eksperimen dan kelas kontrol, untuk membuktikan apakah model pembelajaran $3 C 3 R$ berpengaruh terhadap kemampuan literasi sains siswa, maka selanjutnya dilakukan uji statistik dari kedua kelas berupa uji normalitas, homogenitas dan hipotesis. Hasil analisis perhitungan statistik disajikan pada Tabel 2, 3, dan 4 .

Tabel 2. Hasil perhitungan uji normalitas pada kelas eksperimen dan kelas kontrol

\begin{tabular}{|c|c|c|c|}
\hline Uji normalitas & Kelas & Hasil & Keterangan \\
\hline${ }^{K} \quad(\mathrm{OI}-\mathrm{Ei})^{2}$ & Eksperimen & $\begin{array}{c}x^{2} \text { hitung }=6,56 \\
x^{2} \text { tabel }(0.025)(3)= \\
9,35\end{array}$ & $\begin{array}{c}\text { maka, sampel berasal dari populasi yang } \\
\text { berdistribusi normal }\end{array}$ \\
\hline$L_{\mathrm{I}=1}$ & Kontrol & $\begin{array}{c}x^{2} \text { hitung }=5,63 \\
x^{2} \operatorname{tabel}_{(0.025)(3)}= \\
9,35\end{array}$ & $\begin{array}{c}\text { maka, sampel berasal dari populasi yang } \\
\text { berdistribusi normal }\end{array}$ \\
\hline
\end{tabular}


Tabel 3. Hasil uji homogenitas

\begin{tabular}{|c|c|c|c|c|c|}
\hline $\begin{array}{c}\text { Uji } \\
\text { Homogenitas }\end{array}$ & Kelas & $\mathbf{S}^{2}$ & \multicolumn{2}{|c|}{ Hasil } & Keterangan \\
\hline $\mathrm{F}=\frac{\text { S2 Besar }}{\text { S2 Kecil }}$ & Eksperimen & 0,01 & \multicolumn{2}{|c|}{$\begin{array}{c}F_{\text {hitung }}<\mathrm{F}_{\text {Tabel }}=0,79< \\
1,99\end{array}$} & $\begin{array}{l}\text { maka data memiliki varians yang } \\
\text { homogen }\end{array}$ \\
\hline \multicolumn{6}{|c|}{ Tabel 4. Hasil uji hipotesis } \\
\hline \multicolumn{3}{|c|}{$\begin{array}{c}\text { Uji Hipotesis } \\
\end{array}$} & thitung & tabel & Hasil \\
\hline \multicolumn{6}{|c|}{$t=\frac{X 1-X 2}{2}$} \\
\hline$S g a b \sqrt{\frac{1}{n 1}+}$ & & & 6,845 & 2,051 & Berbeda signifikan \\
\hline
\end{tabular}

Berdasarkan hasil uji normalitas pada kelas kontrol dan kelas eksperimen, dapat dilihat pada (Tabel 2) bahwa dari kedua kelas tersebut diperoleh hasil bahwa nilai $x^{2}$ hitung $<x^{2}$ tabel, yang berarti bahwa pada kedua kelas tersebut populasi nya berdistribusi normal. Kemudian pada uji homogenitas (Tabel 3) diperoleh hasil bahwa nilai $\mathrm{F}_{\text {hitung }}<$ $\mathrm{F}_{\text {Tabel }}$ yang berarti bahwa kedua kelas sampel bersifat homogen. Kemudian pada (Tabel 4) dari hasil uji hipotesis menggunakan uji $\mathrm{t}$ menunjukkan bahwa nilai $t_{\text {hitung }}>t_{\text {tabel }}$ yang berarti bahwa $\mathrm{H}_{0}$ ditolak dan $\mathrm{H}_{1}$ diterima yang menyatakan bahwa terdapat perbedaan yang signifikan pada kemampuan literasi sains siswa antara kelas eksperimen yang menggunakan model pembelajaran $3 C 3 R$ dengan kelas kontrol yang menggunakan pembelajaran konvensional dengan model pembelajaran Group Investigation.

\section{Perbandingan kemampuan literasi sains}

Nilai $N$-gain pada setiap indikator literasi sains diperoleh dari hasil pengolahan rata-rata nilai pretest dan posttest dari setiap indikator literasi sains pada kelas kontrol dan eksperimen. Tujuannya dilakukan penghitungan nilai $N$-gain pada setiap indikator yakni untuk mengetahui perbandingan peningkatan kemampuan literasi sains pada setiap indikator literasi sains setelah diberikan soal pretest dan posttest.
Adapun $N$-gain menurut Hake, (2007) dalam Wiyono, (2013) bahwa $N$-gain disebut juga dengan ternormalisasi rata-rata (average normalized gain).

Adapun indikator literasi sains yang digunakan mengacu kepada indikator literasi sains menurut (OECD, 2016) menggunakan 11 indikator yang terbagi kedalam tiga aspek. meliputi, Aspek menjelaskan fenomena ilmiah yang terdiri dari tiga indikator yakni, mengingat dan menerapkan pengetahuan ilmiah, membuat dan membenarkan prediksi, dan Menjelaskan implikasi potensial pengetahuan bagi masyarakat. Aspek mengevaluasi dan merancang penyelidikan ilmiah terdiri dari tiga indikator yakni, mengidentifikasi pertanyaan yang dieksplorasi, membedakan pertanyaan yang bisa diselidiki secara ilmiah, menjelaskan dan mengevaluasi bagaimana para ilmuwan memastikan keandalan data dan objektivitas serta generalisasi penjelasan. Aspek menafsirkan data dan bukti secara ilmiah terdiri dari lima indikator yakni, mengubah data dari satu representasi ke bentuk lain, menganalisis, menafsirkan data dan menarik kesimpulan, mengidentifikasi asumsi, bukti, dan alasan dalam teks yang berkaitan dengan sains, membedakan antara argumen yang didasarkan pada bukti ilmiah dan teori berdasarkan pertimbangan lain, mengevaluasi argumen ilmiah dan bukti dari berbagai sumber. Berikut ini disajikan sebuah grafik 
(Gambar 1) yang memperlihatkan nilai $N$-gain pada setiap indikator literasi sains, yang diperolah dari hasil pengolahan rata-rata nilai pretest dan posttest dari setiap indikator literasi sains.

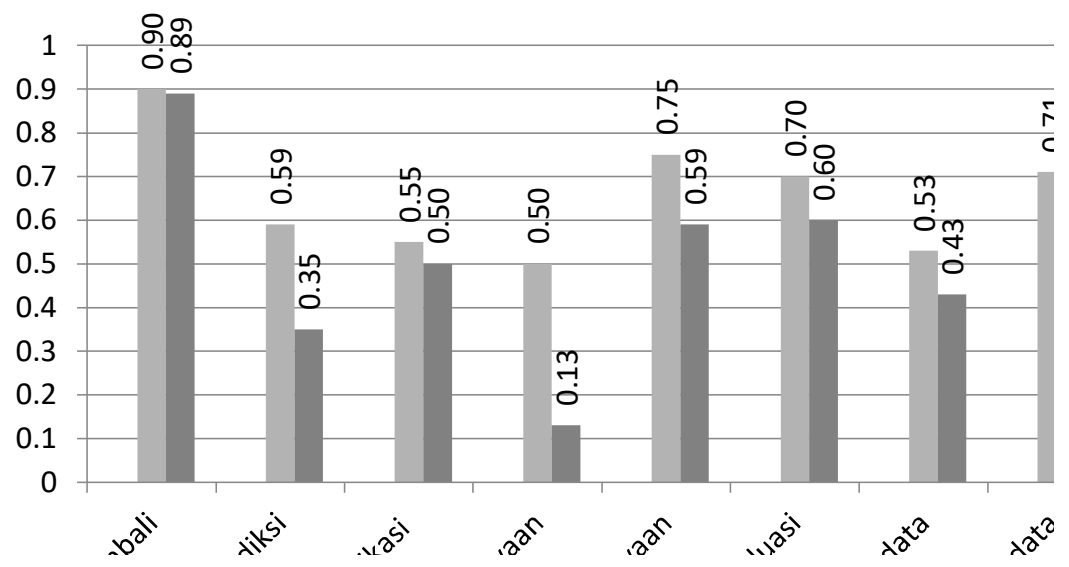

Gambar 1. Grafik perbandingan N-gain setiap indikator

Berdasarkan Gambar 1 di atas nilai $N_{\text {-gain }}$ dari setiap indikator kemampuan literasi sains pada kelas eksperimen maupun pada kelas kontrol memiliki angka yang berbeda-beda. Apabila dibandingkan perolehan nilai $\mathrm{N}$-gain dari setiap indikator literasi sains pada kelas eksperimen lebih tinggi dibandingkan dengan kelas kontrol. Perolehan nilai $N$-gain setiap indikator literasi sains pada kelas eksperimen termasuk kedalam kriteria tinggi $(G \geq 0,7)$ dan sedang $(0,3 \leq \mathrm{G}<0,7)$. Sedangkan perolehan nilai $N$-gain setiap indikator literasi sains pada kelas kontrol termasuk kedalam kriteria sedang dan rendah $(\mathrm{G}<0,3)$.

Nilai $N$-gain indikator literasi sains yang diperoleh pada kelas eksperimen lebih tinggi dibandingkan dengan kelas kontrol disebabkan karena pada kelas eksperimen pada proses pembelajarannya menggunakan model pembelajaran 3C3R. Model pembelajaran tersebut berkaitan dengan konteks kehidupan sehari-hari karena memiliki komponen context. Model pembelajaran tersebut dalam kegiatan pembelajarannya siswa dilatih untuk mencari tau sendiri informasi mengenai content, dan context pada tahap researching content dan researching context kemudian siswa dilatih unuk mencari informasi dengan menghubungkan pengetahuan content dan context yang sudah dimiliki pada tahap researching connection. Tahap tersebut jika dianalisis berhubungan dan dapat melatihkan kemampuan literasi sains siswa pada indikator; mengingat kembali dan menerapkan pengetahuan ilmiah, membedakan antara argumen yang didasarkan pada bukti ilmiah, mengevaluasi argumen ilmiah dan bukti dari berbagai sumber, membedakan pertanyaan yang bisa diselidiki secara ilmiah dan mengidentifikasi pertanyaan yang dieksplorasi dalam studi ilmiah. Hal ini sesuai dengan pendapat menurut Hung, (2012) bahwa dalam model pembelajaran $3 C 3 R$ siswa diarahkan dengan proses mencari tahu.

Kemudian siswa dalam kegiatan pembelajarannya dilatih pula untuk mendiskusikan pengetahuan content dan context yang sudah dimiliki pada tahap sebelumnya dan dilatih pula untuk menghubungkan dari kedua pengetahuan tersebut dengan anggota kelompoknya pada tahap reasoning content, reasoning context, dan rereasoning connection. Tahap tersebut jika dianalisis berhubungan dan dapat melatihkan kemampuan literasi sains siswa pada indikator; menjelaskan 
implikasi potensial dari pengetahuan ilmiah bagi masyarakat, membuat dan membenarkan prediksi yang sesuai, mengubah data dari satu representasi ke bentuk lain, dan menganalisis dan menafsirkan data dan menarik kesimpulan yang tepat. Tahap tersebut mendukung siswa untuk membangun sendiri pengetahuan yang dimilikinya, sesuai dengan pendapat menurut Sunaryo, (2014) mengungkapkan teori belajar yang mendukung model pembelajaran berbasis masalah yaitu teori konstruktivisme sosial Vigotsky yang percaya bahwa pengetahuan tidak bisa ditransfer dari pikiran orang lain ke pikiran seseorang melainkan orang tersebut yang harus membangun sendiri pengetahuannya melalui interaksi dengan orang lain.

Kemudian siswa secara berkelompok mempresentasikan seluruh pembelajarannya di depan kelas pada tahapan reflecting content, reflecting context, reflecting connection. Dalam kegiatan pembelajarannya pun siswa dilatihkan untuk memecahkan masalah yang ada pada kehidupan sehari-hari yang diberikan di awal pembelajaran kemudian siswa mendiskusikan solusi nya pada tahapan reasoning dan mempresentasikannya pada tahapan reflecting. Pemberian masalah yang berkaitan dengan kehidupan sehari-hari, yang dapat melatihkan kemampuan literasi sains didukung oleh pendapat menurut Windyariani, (2018) masalah yang dihadapi dalam kehidupan sehari-hari sesungguhnya adalah masalah yang kontekstual yang dapat diangkat sebagai stimulan untuk mengajarkan literasi sains kepada siswa. Tahap tersebut jika dianalisis berhubungan dapat dan melatihkan kemampuan literasi sains siswa pada indikator; membuat dan membenarkan prediksi yang sesuai, menjelaskan implikasi potensial dari pengetahuan ilmiah bagi masyarakat, menjelaskan dan mengevaluasi bagaimana para ilmuwan memastikan keandalan data, dan objektivitas serta generalisasi penjelasan, mengubah data dari satu representasi ke bentuk lain, dan menganalisis dan menafsirkan data dan menarik kesimpulan yang tepat. Hal tersebut sesuai dengan pendapat Hung, (2012) bahwa komponen pengolahan $3 \mathrm{R}$ yang terdiri dari researching, reasoning, dan reflecting mendukung proses kognitif pemecahan masalah dan keterampilan berpikir yang dimiliki siswa. Penjabaran di atas didukung oleh hasil penelitian Irvani et al. (2017) yang melakukan penelitian mengenai pengaruh integrasi proses 3R (Reseacrhing, Reasoning, Reflecting) pada model PBL terhadap domain pengetahuan literasi sains siswa, bahwa proses $3 \mathrm{R}$ tersebut secara signifikan lebih meningkatkan kemampuan literasi sains siswa.

Selain itu berdasarkan grafik pada Gambar 1 di atas terdapat nilai $N$-gain terendah dan tertinggi pada indikator literasi sains yang diperoleh pada kelas eksperimen maupun kelas kontrol. Indikator yang memperoleh Nilai $N$-gain tertinggi pada kelas kontrol maupun pada kelas eksperimen terletak pada indikator yang sama yakni, pada indikator mengingat kembali dan menerapkan pengetahuan ilmiah yang sesuai. Konsep materi yang dikaitkan pada indikator tersebut berkaitan dengan konsep materi rantai makanan dan komponen biotik abiotik. Indikator tersebut memperoleh Nilai $N$-gain tertinggi pada kelas kontrol maupun pada kelas eksperimen disebabkan, jika pada kelas eksperimen indikator tersebut terlatih dengan model pembelajaran $3 C 3 R$ pada tahapan researching content yakni mencari tahu sendiri informasi yang berkaitan dengan konsep yang dipelajari, yang tersedia pada suatu media. Sesuai dengan pendapat menurut Hung, (2012) dalam model pembelajaran $3 C 3 R$ siswa diarahkan dengan proses mencari tahu, mengemukakan pengetahuan yang mereka miliki serta membantu untuk membentuk hasil 
belajar yang diaplikasikan dalam kehidupan nyata, dan membuat siswa selalu aktif dalam pembelajaran. Sedangkan pada kelas kontrol dengan menggunakan model pembelajaran Group Investigation, pencarian informasi samasama dilakukan tetapi dalam model pembelajaran tersebut siswa tidak mencari informasi secara keseluruhan karena pada setiap kelompoknya siswa hanya memfokuskan pada satu konsep saja. Tetapi walaupun demikian siswa pada kelas kontrol dapat mengingat dengan baik materi yang dipelajari karena siswa menyimak hasil presentasi temannya yang menyampaikan mengenai konsep pelajaran yang telah dipelajari. Sehingga perolehan nilai $N$-gain pada kelas kontrol dan pada kelas eksperimen pada indikator tersebut tidak berbeda signifikan, keduanya memiliki kategori peningkatan yang tinggi yakni, perolehan nilai $N$-gain indikator tersebut pada kelas eksperimen memperoleh nilai sebesar 0,90 sedangkan pada kelas kontrol memperoleh nilai sebesar 0,89 .

Indikator yang memperoleh Nilai $N$-gain terendah pada kelas kontrol maupun pada kelas eksperimen terletak pada indikator yang sama yakni, pada indikator mengidentifikasi pertanyaan yang dieksplorasi dalam studi ilmiah yang diberikan. Konsep materi yang dikaitkan pada indikator tersebut berkaitan dengan konsep materi praktikum mengetahui keadaan Ikan pada air bersih dan tercemar. Walaupun Nilai $N$-gain pada indikator tersebut merupakan $N$-gain terendah pada kelas eksperimen maupun pada kelas kontrol, tetapi apabila dibandingkan antara kelas eksperimen maupun kelas kontrol berdasarkan (Gambar 1) di atas, terlihat bahwa pada kelas eksperimen memperoleh nilai $N$-gain yang jauh lebih tinggi dibandingkan dengan kelas kontrol yakni, perolehan nilai $\mathrm{N}$-gain indikator tersebut pada kelas eksperimen memperoleh nilai sebesar 0,50 sedangkan pada kelas kontrol memperoleh nilai sebesar 0,13. Hal ini disebabkan pada kelas eksperimen Indikator tersebut pada kelas eksperimen dilatihkan melalui model pembelajaran $3 C 3 R$ pada tahapan researching connection melalui kegiatan praktikum terkait konsep materi tersebut. Pada tahapan ini siswa menghubungkan pengetahuan content dan pengetahuan context yang sudah dimiliki yang kemudian dicari informasinya melalui kegiatan pratikum. Tetapi nilai $N$-gain pada indikator tersebut merupakan nilai $N$-gain terendah pada kelas eksperimen maupun pada kelas kontrol. Hal tersebut disebabkan pada kelas eksperimen saat melakukan kegiatan praktikum tersebut, suasana kelas tidak kondusif karena siswa terlalu antusias dengan objek hewan yang akan digunakan pada kegiatan praktikum, sehingga proses researching connection pada kegiatan praktikum untuk mengidentifikasi pertanyaan penelitian kurang dilakukan dengan baik. Hal ini sesuai dengan salah satu kelemahan model pembelajaran 3C3R bahwa salah satunya siswa mudah melepas diri dari keterlibatan dan tidak memperhatikan. (Burhanudin, et al., 2018). Sedangkan pada kelas kontrol dengan menggunakan pembelajaran konvensional dengan model pembelajaran Group Investigation, kemampuan ini sama sekali tidak dilatihkan dan proses menghubungkan pengetahuan content dan context tidak terjadi pada tahapan pembelajarannya, dan juga tidak berhubungan dengan tahapan pembelajarannya, sehingga kemampuan tersebut kurang terlatihkan. Hal tersebut berkaitan dengan salah satu kelemahan dari model pembelajaran Group Investigation yakni model pembelajaran tersebut memerlukan pengaturan situasi dan kondisi yang berbeda, jenis materi yang berbeda, keadaan kelas tidak selalu memberikan lingkungan fisik yang baik bagi kelompok, dan keberhasilan pembelajaran dengan model pembelajaran tersebut bergan- 
tung pada kemampuan siswa memimpin kelompok atau bekerja mandiri. (Wijayanti, et al., 2013).

\section{KESIMPULAN}

Berdasarkan hasil penelitian yang telah dilakukan, bahwa model pembelajaran 3C3R berpengaruh terhadap kemampuan literasi sains siswa. Dari hasil uji t menunjukkan thitung $>t_{\text {tabel }}(6,845>2,051)$ bahwa artinya terdapat perbedaan yang signifikan pada kemampuan literasi sains siswa antara kelas eksperimen dan kalas kontrol. Hasil uji statistik menunjukkan bahwa sampel berdistribusi normal dan homogen. Penggunaan model pembelajaran yang menekankan pada aspek kontekstual dan pemcahan masalah dapat mempengaruhi kemampuan literasi sains, salah satunya melalui model pembelajaran $3 C 3 R$. Hal ini didukung oleh penelitian sebelumnya yang menyatakan bahwa proses researching, reasoning, dan reflecting pada lingkungan belajar dapat meningkatkan kemampuan literasi sains. Manfaat dari penelitian ini dapat mempengaruhi kemampuan literasi sains siswa menjadi lebih baik yang akan berguna bagi siswa.

\section{DAFTAR PUSTAKA}

Burhanudin, R., Subarkah, C. Z., \& Sari, S. (2018). Penerapan model pembelajaran content context connection researching reasoning reflecting (3C3R) untuk mengembangkan keterampilan generik sains siswa pada konsep koloid. Jurnal Tadris Kimiya.

https://doi.org/10.15575/jtk.v3i1.2595

Hung, W. (2012). The 3C3R Model: A Conceptual Framework for Designing Problems in PBL. Interdisciplinary Journal of Problem-Based Learning. https://doi.org/10.7771/1541-5015.1006

Hung,W. (2009). The 9-step problem design process for problem-based learning: Application of the 3C3R model. Educational Research Review.

Husna, A., \& Himmi, N. (2019). Pengembangan modul berbasis konstruktivisme pada mata kuliah analisis vektor di UNRIKA.
PYTHAGORAS: Jurnal Program Studi Pendidikan Matematika.

Kusuma Astuti, Y. (2016). Literasi Sains Dalam Pembelajaran IPA. Issn, 7(3B), 1693-7945.

Munasinghe, S. R., Senaviratne, P. A. U. K., Liyanapatabandi, D., \& Olupeliyawa, O. M. (2010). Designing and implementation of a problem based learning (PBL) programme with real life case scenarios for the management of transfusion related adverse reactions. Journal Vox Sanguinis. .

Odja, A. H., \& Payu, C. S. (2014). Analisis Kemampuan Awal Literasi Sains Siswa Pada Konsep IPA. Prosiding Seminar Nasional Kimia,. https://doi.org/10.33086/ehdj.v1i1.291

OECD Publishing. (2016). PISA 2015 Assessment and Analytical Framework: Science, Reading, Mathematic and Financial Literacy,. In $O E C D$ Publishing. https://doi.org/10.1787/9789264255425-en

Shofiyah, N. (2016). Deskripsi Literasi Sains Awal Mahasiswa Pendidikan IPA Pada Konsep IPA. PEDAGOGIA: Jurnal Pendidikan. https://doi.org/10.21070/pedagogia.v4i2.13

Sunaryo, Y. (2014). Model Pembelajaran Berbasis Masalah Untuk Meningkatkan Kemampuan Berpikir Kritis Dan Kreatif Matematika Siswa SMA Di Kota Tasikmalaya. Jurnal Pendidikan Dan Keguruan. https://doi.org/10.1007/s13398014-0173-7.2

Techakosit, S., \& Wannapiroon, P. (2015). Connectivism Learning Environment in Augmented Reality Science Laboratory to Enhance Scientific Literacy. Procedia - Social and Behavioral Sciences. https://doi.org/10.1016/j.sbspro.2015.02.009

Udompong, L., \& Wongwanich, S. (2014). Diagnosis of the Scientific Literacy Characteristics of Primary Students. Procedia Social and Behavioral Sciences. https://doi.org/10.1016/j.sbspro.2014.01.1079

Wijayanti, W., Herlambang, S., \& K, M. S. (2013). Pengaruh model pembelajaran group investigation (gi) terhadap kemampuan berpikir kritis siswa kelas $\mathrm{x}$ sma negeri 1 mejayan kabupaten madiun. Jurnal Pendidikan Geografi Universitas Negeri Malang.

Windyariani, S. (2018). Kemampuan literasi sains siswa sd pada konteks melestarikan capung. BIOSFER: Jurnal Pendidikan Biologi, 10(1), 17 21, https://doi.org/10.21009/biosferjpb.

Wiyono. (2013). Pembelajaran matematika model concept attainment meningkatkan kemampuan pemecahan masalah materi segitiga . Journal of Educational Research and Evaluation. 2(1), 0-4. 